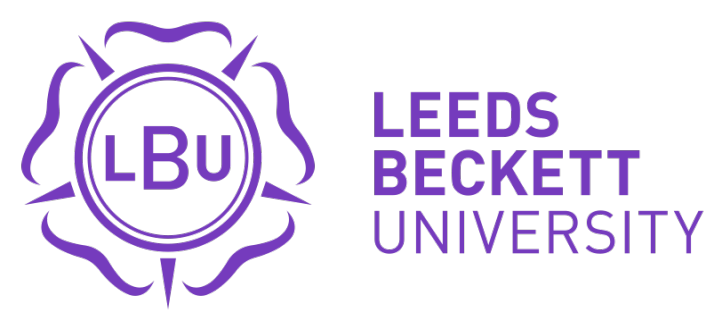

Citation:

Muleya, F and Mulenga, B and Zulu, S and Nwaubani, S and Tembo, C and Mushota, H (2020) Investigating the suitability and cost-benefit of copper tailings as partial replacement of sand in concrete in Zambia: An exploratory study. Journal of Engineering, Design and Technology. ISSN 1726-0531 DOI: https://doi.org/10.1108/JEDT-05-2020-0186

Link to Leeds Beckett Repository record:

https://eprints.leedsbeckett.ac.uk/id/eprint/7044/

Document Version:

Article (Accepted Version)

The aim of the Leeds Beckett Repository is to provide open access to our research, as required by funder policies and permitted by publishers and copyright law.

The Leeds Beckett repository holds a wide range of publications, each of which has been checked for copyright and the relevant embargo period has been applied by the Research Services team.

We operate on a standard take-down policy. If you are the author or publisher of an output and you would like it removed from the repository, please contact us and we will investigate on a case-by-case basis.

Each thesis in the repository has been cleared where necessary by the author for third party copyright. If you would like a thesis to be removed from the repository or believe there is an issue with copyright, please contact us on openaccess@leedsbeckett.ac.uk and we will investigate on a case-by-case basis. 


\title{
Investigating the suitability and cost-benefit of copper tailings as partial replacement of sand in concrete in Zambia: An exploratory study
}

\begin{abstract}
Purpose: - This study investigated the suitability and cost-benefit of using copper tailings as partial replacement of sand in concrete production. The study was motivated by the accumulation and nonutilisation of Copper Tailings in dams among them Tailing Dam 25 also known as TD 25 in Kitwe city of the Copperbelt province in Zambia that take up approximately 111 hectares of unutilized land.

Design/methodology/approach: - Laboratory experimental approach of concrete production based on water/cement ratios of 0.3 and 0.5 was used because this was an exploratory study designed to establish the primary performance of concrete. 30 concrete cubes were cast based on the two water-cement ratios. $0 \%$ to $30 \%$ partial sand replacement with copper tailings was used in both mixes with the $0 \%$ copper tailings replacement being the control mix and reference point. Other concrete tests included workability, density, compressive strength and element composition analysis.
\end{abstract}

Findings: - Results revealed that copper tailings from TD 25 were suitable for partial replacement of sand in concrete. $30 \%$ of sand replacement with copper tailings was established as the maximum replacement amount to produce optimum compressive strength values from both mixes. The drier mix of 0.3 water-cement ratio produced higher compressive strength results of $23 \mathrm{MPa}$ at 28 days of concrete curing with $2.34 \%$ as optimum concrete cost reduction.

Originality/Value:- The study provides guidance on optimum concrete grade produced and cost reduction details of copper tailing-based concrete to support for local authorities in suitable land wand waste management using real data.

Keywords: Concrete, Partial replacement, Sand, Copper tailings, Cost-benefit, sustainability

\section{Introduction}

Concrete is one of the most important construction materials that is used in the construction of structural elements in infrastructure development worldwide. Aggregates act as the main constituent materials of concrete in addition to cement and water and account for 60 to $75 \%$ of concrete by volume and 70 to $85 \%$ by mass (Maza et al., 2015). The type of aggregates utilised are coarse and fine. During the hydration process, coarse aggregates are bonded with cement to form cement concrete while fine aggregates fill the gaps between the coarse aggregate (Beniwal et al., 2015). Shettima et al., (2016) argue that increased consumption of natural fine aggregate in an ever-growing construction industry reduces the natural resources which are diminishing and irreplaceable. In addition, Shettima et al., (2016) states the increase in the consumption of fine aggregate for construction activities leads to overexploitation of river beds. It is estimated that more than 2 billion tonnes of carbon dioxide had been emitted from the production of Portland cement between 2006 and 2016. As such, the increasing global consumption of cement and concrete has led to discussions concerning alternative materials for use pin the cement production process (Possan et al., 2016).

There is an acknowledgement in the literature of the need to the use natural aggregate in the concrete production process and one of the options available is to partially replace natural fine 
aggregates or sand with safe recyclable material such as copper tailings, gold tailings or iron ore tainings (Preethi et al., 2017; Parthasarathi et al., 2016; Sunil et al., 2016; Gupta et al., 2017). Studies such as Onuguluchi and Eren (2012) have demonstrated that industrial byproducts like silica fume, coal fly ash and granulated blast furnace slag can be used as partial elements in the production of durable concretes. The utilisation of these industrial by-products such as aggregates and cement replacement materials in concrete present monetary and environmental benefits such as savings in disposal cost, zero- cost raw material and a cleaner environment Onuguluchi and Eren (2012). Furthermore, Senthamarai and Devadas (2005) reported that industrial and other wastes used in concrete making have the potential to improve concrete properties and reduce its cost thereof. The present study focuses on the use of copper tailings as a replacement of sand in cement production in Zambia.

\section{Research Background and motivation}

Copper tailings are a waste material produced from the concentration of copper to copper concentrates (Gou et al., 2019) with a copper content of less than 0.01\% (Sikaundi, 2008). Once minerals of value have been extracted from the ore, the residuals rich in gangue minerals are discharged as tailings. As a result, large quantities of copper tailings are generated every year. Tailings are mainly transported as a slurry in a pipeline to a disposal facility referred to as a tailings dam (Beniwal et al., 2015). Disposal of copper tailings has long been regarded as an environmental challenge because of the hazards of earth and aquatic pollution. Tailings form of slurry are pumped through a pipeline from the concentrator to the nearby storage facilities, such as cross valleys, hillside dams, raised embankments and dry-stacking of thickened tailings on land (Edraki et al., 2014). The disposal of copper tailings is one of the environmental challenges in the copper mining industry. Particles in tailings may cause air pollution in summer season and erosion of tailings in the rainy season which affects the nearby land, surface water and underground water sources (Shamsai et al., 2007). Mulenga (2017) states that major environmental impacts of tailings dams apart from visual effects on the landscape include but are not limited to surface water pollution arising from the discharge of wastewater contaminated with solids, heavy metals, mill reagents, sulphur compounds. Others include air pollution arising from nuisance dust particles blown by wind if the dumpsite is not vegetated, Large areas of land becoming barren, pollution of underground water sources if the dump is located in geo- technically unsuitable site. According to (Esmaeili et al., 2020), the disposal of copper mine tailings (CMT) in sites close to human settlements remains a serious human safety and environmental management hazard in most copper-producing countries of the world.

To prevent uncontrolled disposal of copper tailings material into the atmosphere copper mines normally own dumping facilities in the form of dams or ponds (Thomas et al., 2013). This is a convenient way of storage when tailings are usually in the form of slurry after they are discharged from the concentrator. Kumar and Skariah (2012) states that tailing disposal through slurry dumping requires more additional land than necessary. The amount of tailing produced in the copper extraction process can be as high as 196.5 tons of solid and liquid tailing for every ton of copper extracted (Bridge, 2000). Waste generation from copper production in Zambia was at its highest in the early 1990s when the country produced an estimated 38 million tons of solid wastes per annum of which $90 \%$ was mining waste including copper tailings which ended up in tailing dams (Banda, 1993). There are at least 21 waste rock dumps covering more than 388 hectares, 9 slag dumps covering 279 hectares and more than 45 tailing dams covering an area estimated at 9125 hectares in Zambia (Lindah, 2014; Sikaundi, 2008; and Yamba, 2004). This mineral waste represents a "loss of opportunity" for the local population in terms of land for agriculture, forestry, housing, industrial and commercial building development. 
While the majority of these dumpsites are no longer operational, and therefore not increasing in size, they remain an environmental concern. Today TD25 is still in existence with the same volume of 27 million tonnes of copper tailings according to Misenge Environmental and Technical services, an environmental wing of the ZCCM-IH, which is an agency of the Zambian government responsible for managing mining shares on behalf of the Zambian government.

Siluonde (2016) indicates that cheap ways of dealing with copper tailing dumps were being sought after in 2009 citing two tailing dumping sites in Kitwe namely Kitwe (TD25) and Uchi (TD26) tailing dams. It is estimated that the rehabilitation of both dumps containing up to 35.4 million tons of waste would cost the Zambia Consolidated Copper Mines Investment Holdings (ZCCM-IH) over $\$ 2.4 \mathrm{~m}$ (Siluonde, 2016). The country could avoid these costs if sustainable and economical means of utilising the copper tailings were established. There are ongoing discussions of approaches to effectively utilise copper tailings in the closed damp-sites in Zambia to avoid high rehabilitation costs. . The planned rehabilitation of tailing dams in Copperbelt Province was aimed at assisting the Zambian government to address some of the accrued environmental liabilities, by piloting closure of few old mine tailing dams (Lindah, 2014; Sikaundi, 2008; and Yamba, 2004).

The (World Bank, 2011) highlighted that Zambia was on course to achieve the government's target of 1.5 million tons of copper output per year from 820,000 tons in 2010. If Zambia could reach the projected copper production target, it could become the $3^{\text {rd }}$ largest producer of copper in the world (World Bank, 2011) Consequently, an increase in copper production means increased waste generation. Given the background and challenges presented by the copper tailing dams, the purpose of this research was therefore to investigate the suitability of utilising copper tailings as a partial replacement of fine aggregates in concrete. The use of copper tailings as a waste material can provide solutions to solving problems related to the limited supply of aggregate in various construction projects, freeing up productive land and reducing environmental problems related to aggregate mining and waste disposal. The use of waste aggregates reduces the cost of bulk concrete production. The focus of this research was Kitwe Tailing Dam 25 (TD 25) whose location map is shown in figure 1. Results from literature reviewd in this paper suggest that different tailings from different dams have properties making tailings from each dam unique The aim of this study was, therefore, to explore the suitability and cost-benefit of using Zambia's copper mine tailings as partial replacement of sand in concrete production. 


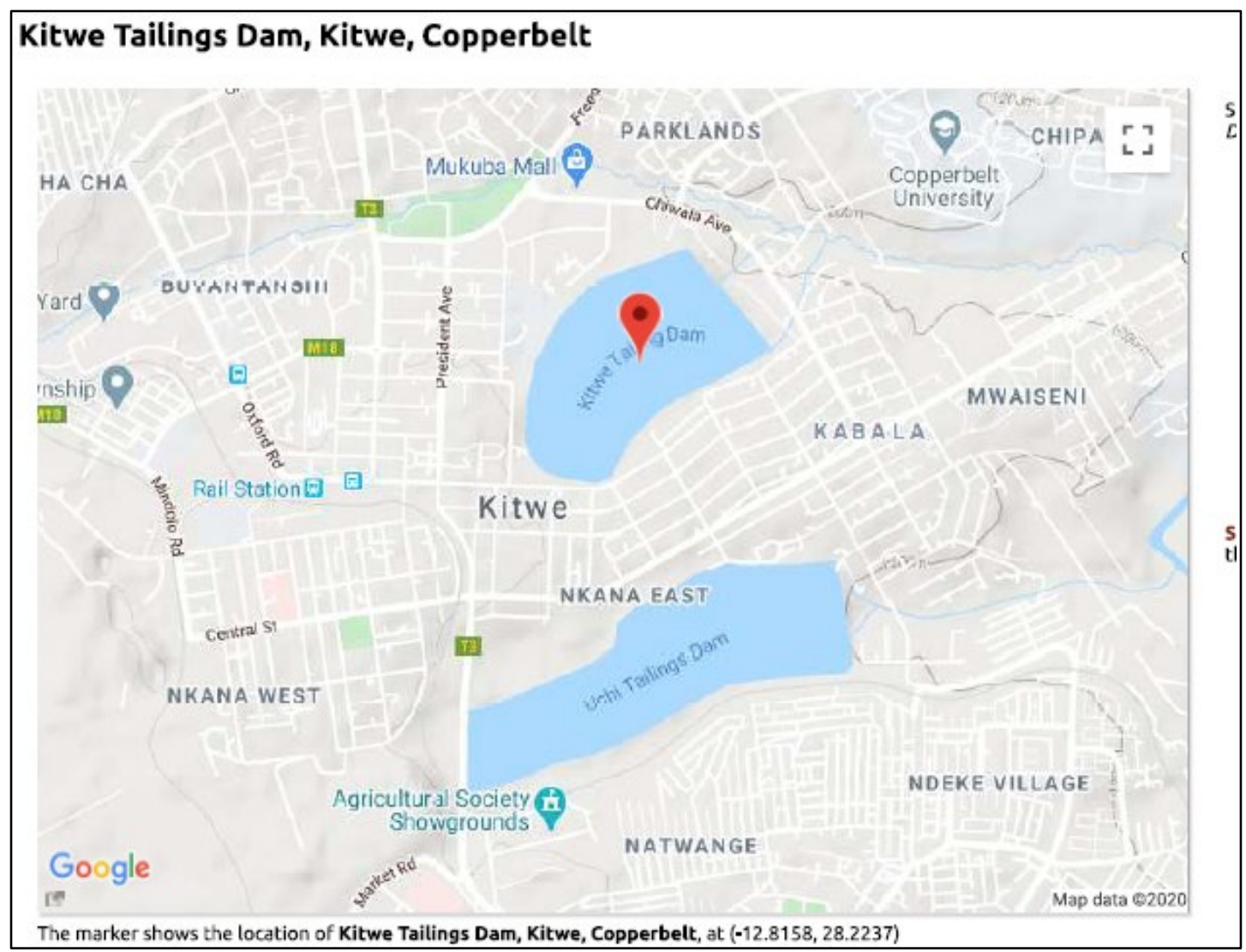

Insert Figure 1: Kitwe map showing tailing dams TD25 and TD 26, source,

https://www.xeno-canto.org/location/map?lat=-

$\underline{12.8158 \& \text { long }=28.2237 \& \text { loc }=\text { Kitwe }+ \text { Tailings }+ \text { Dam } \% 2 C+\text { Kitwe } \% 2 C+\text { Copperbelt }}$

\section{Copper tailings as recyclable material}

Copper tailings and electric arc furnace (EAF) steel slag are among the common waste materials used in road construction (Sorlini et al., 2012; Pasetto and Baldo, 2011). The use of copper tailings has significantly contributed to cleaner technology because their use has preserved natural ecosystem through reduced amounts of dumped waste and consumption of conventional aggregates in asphalt production (Pasetto and Baldo, 2010; Liapis and Likoydis, 2012; Motz and Geiseler, 2001). Sultan (1979) investigated the possibility of using stabilised copper mine tailings in road construction and the findings indicated that copper mine tailings contain high engineering qualities and thus could be incorporated in highway construction (Bandhopadhyay et al., 1993). (Saxena et al., 2004) reports on the production of comparatively higher strength bricks prepared with copper tailings waste. Production of glass wool and glass fibre has been exploited using copper tailings as a source of silica by the researchers (Saxena and Gowri, 2002). Gupta et al., (2012) investigated the stabilisation of clayey soil using copper tailings was explored. They argued that the expansive soils could be stabilized by the combination of clay and copper. Onuaguluchi and Eren (2013) studied the rheology, strength and durability properties of mortars containing copper tailings as a cement replacement material and demonstrated that the substitution of cement with copper tailings led to an increase in yield stress of mortar mixtures, decrease in flow spread and higher resistance to chloride penetration. 
An attempt was made in another study to utilise copper tailings in paints as an extender. Saxena and Dhimole (2006) experimented on the utilisation and value addition of copper tailing as an extender for the development of paints. The results revealed that copper tailings waste has good potential to be used as an extender in paints with respect to oil absorption, $\mathrm{pH}$ and specific gravity. Other studies have focused on the recycling of copper tailings in the production of autoclaved aerated concrete and other products such as tiles and bricks. Huang et al., (2012) and Feng-qing et al., (2009) reported that copper tailings and blast furnace slag can be used as a substitution of lime to produce autoclaved aerated concrete products and bricks by providing Calcium Oxide and Magnesium Oxide compositions. In addition, an experimental study revealed that copper tailings could be used in attaining in self-compacting concrete (SCC) with up to $20 \%$ of fine aggregate being replaced by tailings (Jankovic et al., 2015). The blending of copper tailings with other raw materials in the production of unglazed tiles was investigated by (Marghussian and Maghsoodipoor, 1999). The results revealed that tiles containing 40\% copper tailings fired at $1025{ }^{\circ} \mathrm{C}$ for 1 hour presented good mechanical and acid-resistant properties. Similarly, Çoruh et al., (2006) observed that copper flotation waste vitrified at 850 ${ }^{\circ} \mathrm{C}$ for 2 hours, formed glass-ceramic products with very good chemical durability. Chen et al., (2011) presents the ratios of combining copper tailings, fly ash and clay in the production of good quality bricks based on compressive strength, water absorption and bulk density. The studies cited above demonstrated that copper tailings have the potential to be used in the production of various construction-related materials.

Esmaeili et al., (2020) investigated the reuse of the copper mine tailings (CMT) was evaluated as a partial substitute material for cement in paste, mortar, and concrete mixtures in Iran. They used tailings taken from the Sungun open cast mining in Northern Iran which produces approximately 13.7 million tonnes of copper tailings are generated as solid waste annually as a result of mining and ore processing activities. Results from their study showed that the products were compliant with product requirements including sustainability and environmental benefits despite an increase in water demand. This study established successful production of concrete based on waste tailings of Sungun as a partial substitute for cement in concrete with up to 30\% cement replacement. Gupta et al., (2017) investigated the strength, permeability, abrasion, carbonation, and shrinkage characteristics of concrete containing various percentages of copper tailing as partial replacement of natural fine aggregates with $80 \%$ as a maximum replacement for non-structural applications and $70 \%$ and below for structural applications. It is evident that the performance of these tailings exceeds the usual performance from general literature suggesting that copper tailings from each dam or dump site must be tested for properties and performance because of variations as seen from the Sungun copper tailings.

It must be stated that copper tailings from each dam must be investigated for performance in concrete because copper tailings from different sources could contain different properties leading to varying outputs in terms of compressive strengths and other concrete properties. From literature, it is clear that copper mine tailings have been used in sand and cement partial replacement mainly up to $30 \%$. Literature also suggests that copper tailings from each dump site must be tested to establish the properties and effects on concrete including the extent of partial cement or fine aggregate replacement. Whilst many of the papers cited indicate the use of copper tailings, this paper goes beyond to carry out a cost-benefit analysis by attaching figures to cost and land use benefits to the local authority and surrounding community.

\section{Research Methodology}

Kumar (1996) refers to research design as a plan, structure and strategy of investigation to obtain answers to research questions or problems. This research was quantitative in nature 
which Creswell (2009) defines as an approach that supports an experimental strategy in its inquiry. The study philosophically was positivist and therefore deductive. The research was dominantly experimental supported by a literature review on the use of copper tailings in concrete production. The experimental section investigated the suitability of copper tailings from tailing dam 25 (TD 25) in Kitwe, Zambia as partial replacement of sand in concrete. Further, the optimum percentage of fine aggregates that can be replaced by copper tailings in concrete production was determined. Laboratory experiments were carried out to achieve the aim of the study. These tests included physical and element composition tests on the fine aggregates (i.e. sand and copper tailings) and the developed concrete. Fresh concrete was made to measure the concrete slump and workability. Slump tests and compaction factor tests were used to establish concrete workability and later cast three concrete cubes for each mix to get the average reading for each mix for quality control purposes. A total of 30 concrete cubes including trial mixes were cast and cured for 28 days underwater in a curing tank to obtain estimated maximum strength of the concrete cubes.

The study aim was focused on the final concrete product for use by end-users as an exploratory study and therefore all cubes were crushed at 28 days except for trial cubes which were tested at 7 days to check the normality of the concrete gain of strength. Hallingberg et al., (2018) define exploratory research as s study which aims to generate the evidence needed to decide whether and how to proceed with a full-scale effectiveness trial or other study design labelled as exploratory/pilot/feasibility/phase as proof of concept. The Hard-concrete tests included the density test and compressive strength which was attained using a digital compressive strength testing machine as shown in figure 11. All the fresh and hard concrete results are shown in table I and table II. The control mix had no copper tailings content while other mixes had copper tailings added from $10 \%$ to $30 \%$ as a maximum replacement. Details of the research design are contained in figure 3. Element composition tests included element analysis of the copper tailings to check for the presence of elements that could cause a harmful reaction in the concrete. The principle of isolated analysis was used to determine the optimum percentage of fine aggregate replacement. Muleya (2015) describes isolated analysis as the process of holding all variables constant while manipulating one of them to determine its influence on the properties of the entire element. Emmitt and Gorse (2014) designed mixes of concrete are those where strength is the main criterion of the specified mix, which is judged based on strength tests. The variable under manipulation in this research was the copper tailings which were added in percentages ranging from $0-30 \%$ to determine the effect on concrete workability, density and compressive strength of concrete. Laboratory concrete tests with concrete water/cement ratios of 0.3 and 0.5 were used to determine the suitability of the copper tailing as partial replacement of sand in concrete. The experiments were limited to the tests and procedures laid out in figure 3:

\section{Elemental composition of the copper tailings}

Element composition analysis of the copper tailings was carried out using the spectrometer machine to identify elements in the copper tailings that had the potential to react with cement and cause the concrete to react. The tailings were found to have low sulphate content which is one of the unwanted elements in concrete. Further the results showing all elements in the copper tailings as reported in figure 2 indicated that there was no element with the potential to react with the concrete when mixed with copper tailings from TD 25. The highest element was oxygen followed by silicon, aluminium and magnesium. The rest of the elements were negligible including the notorious sulphur was only $0.02 \%$ by mass. 


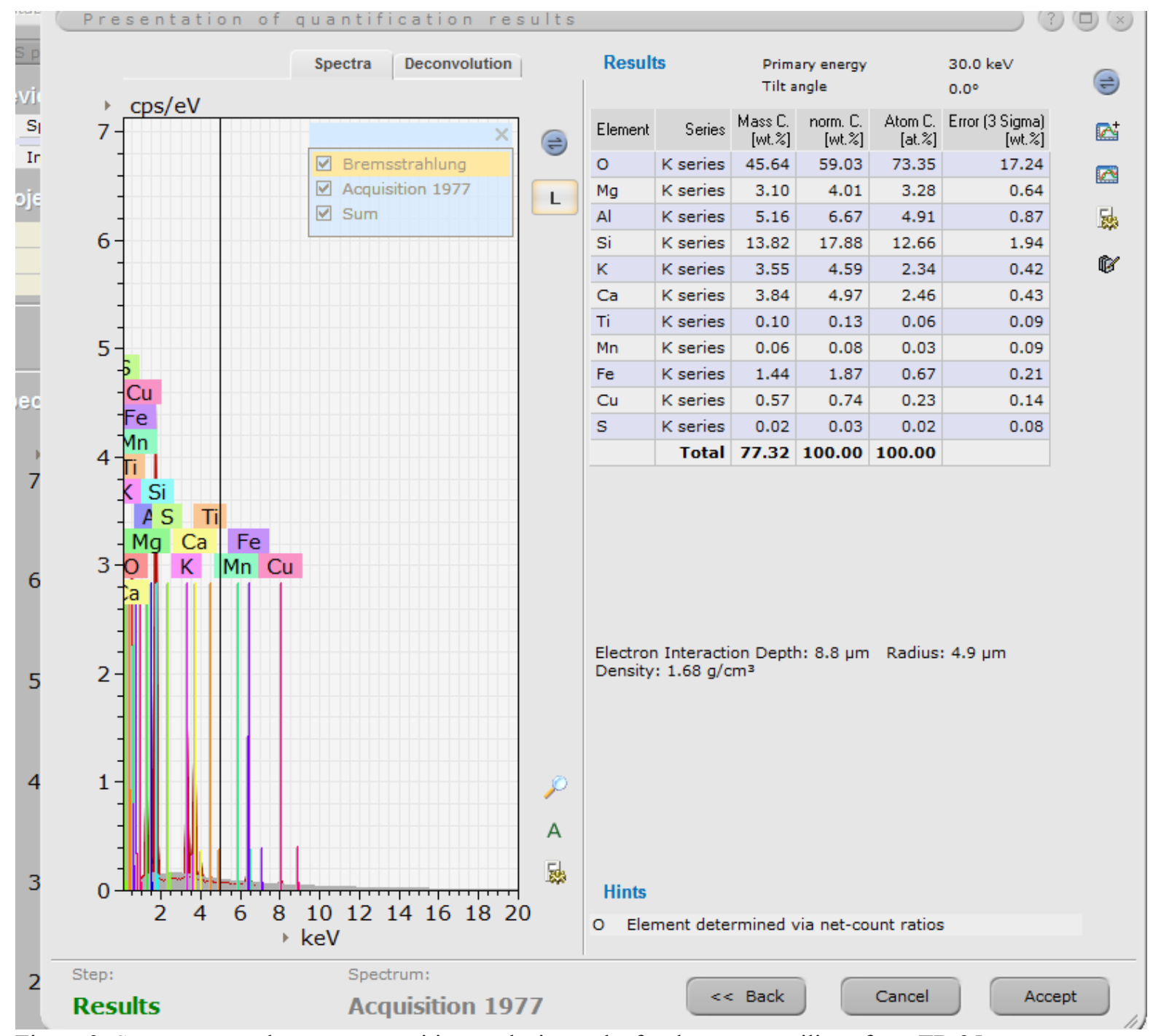

Figure 2: Spectrometer element composition analysis results for the copper tailings from TD 25

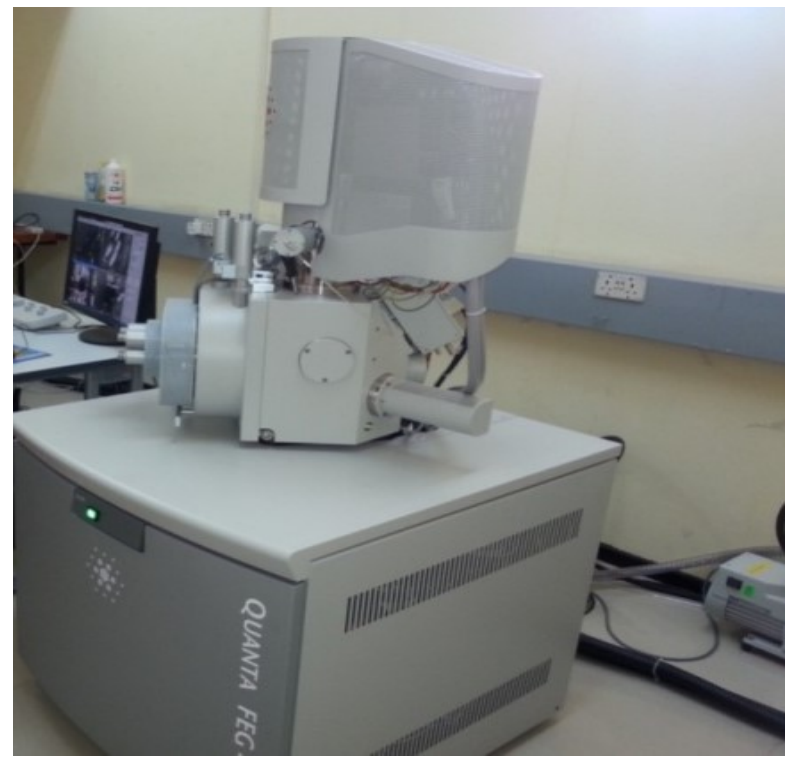

Plate 1: Spectrometer machine used for elemental analysis of copper tailings 


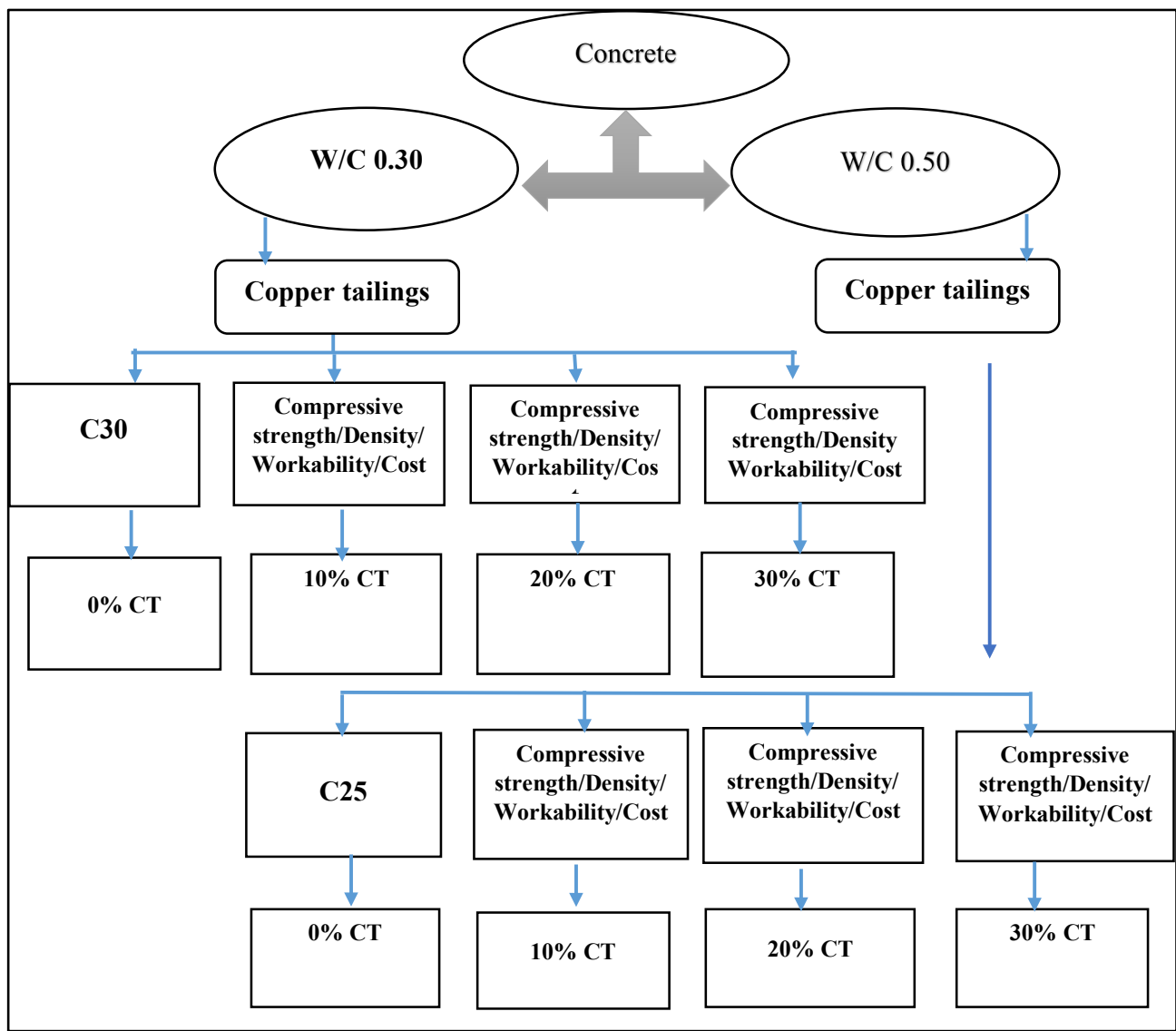

Figure 3: laboratory experimental design

Plates 2 to 7 shows the processes involves in the preparation of the concrete in the laboratory.

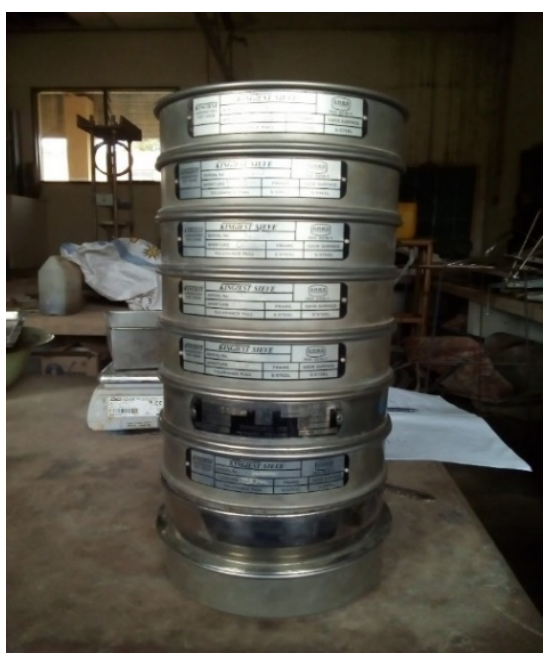

Plate 2: Sieve analysis for fine aggregates and copper tailings 


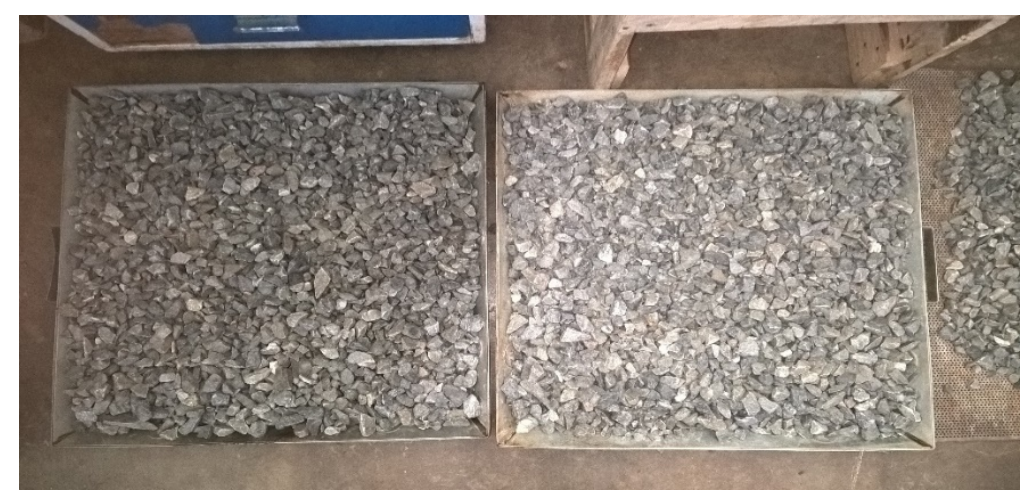

Plate 3: 10mm coarse aggregate in readiness for casting for the concrete

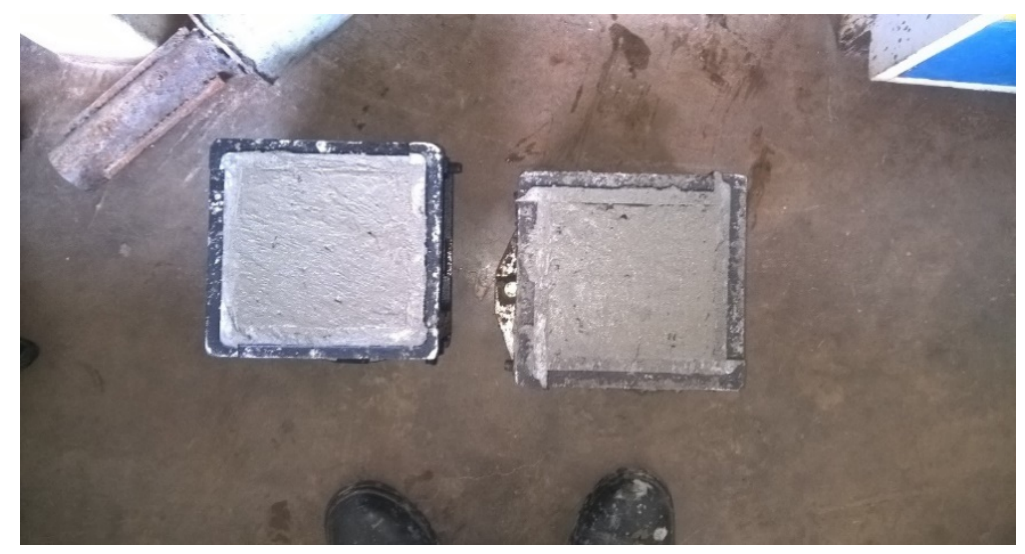

Plate 4: Fresh concrete cubes cast

\section{Results and discussion}

This section discusses and analyses fresh and hard concrete results from the laboratory experiments. The section further presents the cost-saving profile of concrete associated with the partial replacement of sand with copper tailings from TD 25. A summarised and consolidated table of fresh and hard concrete results are presented tables I and II. 
Table I: Consolidated concrete results for concrete with a water-cement ratio of 0.3 Consolidated laboratory results for concrete with water cement ratio 0.3

\begin{tabular}{|c|c|c|c|c|c|c|c|}
\hline \multicolumn{2}{|l|}{$\begin{array}{c}\text { Mix } 1 \\
\text { (0\% Copper tailing) } \\
\end{array}$} & \multicolumn{2}{|l|}{$\begin{array}{c}\text { Mix } 2 \\
\text { (10\% Copper tailings) }\end{array}$} & \multicolumn{2}{|l|}{$\begin{array}{c}\text { Mix } 3 \\
\text { (20\% Copper tailings) } \\
\end{array}$} & \multicolumn{2}{|l|}{$\begin{array}{c}\text { Mix } 4 \\
\text { (30\% Copper tailings) }\end{array}$} \\
\hline $\mathrm{W} / \mathrm{C}$ & 0.3 & $\mathrm{~W} / \mathrm{C}$ & 0.3 & W/C & 0.3 & W/C & 0.3 \\
\hline Materials & & Materials & & Materials & & Materials & \\
\hline Cement (Kg) & 5.9 & Cement (Kg) & 5.9 & Cement $(\mathrm{Kg})$ & 5.9 & Cement (Kg) & 5.9 \\
\hline Copper tailings (Kg) & 0 & Copper tailings (Kg) & 0.88 & Copper tailings (Kg) & 1.76 & Copper tailings (Kg) & 2.64 \\
\hline Sand (Kg) & 8.8 & Sand (Kg) & 7.92 & Sand (Kg) & 7.04 & Sand (Kg) & 6.16 \\
\hline Stone $(\mathrm{Kg})$ & 17.6 & Stone $(\mathrm{Kg})$ & 17.6 & Stone $(\mathrm{Kg})$ & 17.6 & Stone $(\mathrm{Kg})$ & 17.6 \\
\hline Free water $(\mathrm{Kg})$ & 1.77 & Free water $(\mathrm{Kg})$ & 1.77 & Free water $(\mathrm{Kg})$ & 1.77 & Free water $(\mathrm{Kg})$ & 1.77 \\
\hline Absorbed water (FA) (Kg) & 0.64 & Absorbed water (FA) (Kg) & 0.64 & Absorbed water (FA) (Kg) & 0.64 & Absorbed water (FA) (Kg) & 0.64 \\
\hline Results & & Results & & Results & & Results & \\
\hline Slump (mm) & 5 & Slump (mm) & 6 & Slump (mm) & 7 & Slump (mm) & 10 \\
\hline Compaction Factor & 0.7 & Compaction Factor & 0.71 & Compaction Factor & 0.7 & Compaction Factor & 0.71 \\
\hline Cement $\left(\mathrm{kg} / \mathrm{m}^{3}\right)$ & 400 & Cement $\left(\mathrm{kg} / \mathrm{m}^{3}\right)$ & 400 & Cement $\left(\mathrm{kg} / \mathrm{m}^{3}\right)$ & 400 & Cement $\left(\mathrm{kg} / \mathrm{m}^{3}\right)$ & 400 \\
\hline Density Compacted concrete $\left(\mathrm{kg} / \mathrm{m}^{3}\right)$ & 2356 & Density Compacted concrete $\left(\mathrm{kg} / \mathrm{m}^{3}\right.$ & 2359 & Density Compacted concrete $\left(\mathrm{kg} / \mathrm{m}^{3}\right)$ & 2306 & Density Compacted concrete $\left(\mathrm{kg} / \mathrm{m}^{3}\right)$ & 2296 \\
\hline
\end{tabular}

Table II: Consolidated concrete results for concrete with a water-cement ratio of 0.5

Consolidated laboratory results for concrete with water cement ratio 0.5

\begin{tabular}{|c|c|c|c|c|c|c|c|}
\hline \multirow{2}{*}{\multicolumn{2}{|c|}{$\begin{array}{c}\text { Consolidated laboratory results for concrete with } \\
\text { Mix } 5 \\
\text { ( } 0 \% \text { Copper tailing) }\end{array}$}} & \multirow{2}{*}{\multicolumn{2}{|c|}{$\begin{array}{c}\text { ter cement ratio } 0.5 \\
\text { Mix } 6 \\
(10 \% \text { Copper tailings })\end{array}$}} & \multirow{2}{*}{\multicolumn{2}{|c|}{$\begin{array}{c}\text { Mix } 7 \\
\text { (20\% Copper tailings) }\end{array}$}} & \multirow{2}{*}{\multicolumn{2}{|c|}{$\begin{array}{c}\text { Mix } 8 \\
\text { (30\% Copper tailings) }\end{array}$}} \\
\hline & & & & & & & \\
\hline $\mathrm{W} / \mathrm{C}$ & 0.5 & $\mathrm{~W} / \mathrm{C}$ & 0.5 & W/C & 0.5 & W/C & 0.5 \\
\hline Materials & & Materials & & Materials & & Materials & \\
\hline Cement (Kg) & 4 & Cement (Kg) & 4 & Cement (Kg) & 5.9 & Cement (Kg) & 4 \\
\hline Copper tailings (Kg) & 0 & Copper tailings (Kg) & 0.88 & Copper tailings (Kg) & 1.76 & Copper tailings (Kg) & 2.64 \\
\hline Sand (Kg) & 8.8 & Sand $(\mathrm{Kg})$ & 7.92 & Sand $(\mathrm{Kg})$ & 7.04 & Sand $(\mathrm{Kg})$ & 6.16 \\
\hline Stone $(\mathrm{Kg})$ & 17.6 & Stone $(\mathrm{Kg})$ & 17.6 & Stone $(\mathrm{Kg})$ & 17.6 & Stone $(\mathrm{Kg})$ & 17.6 \\
\hline Free water $(\mathrm{Kg})$ & 2 & Free water (Kg) & 2 & Free water (Kg) & 2 & Free water $(\mathrm{Kg})$ & 2 \\
\hline Absorbed water (FA) (Kg) & 0.64 & Absorbed water (FA) (Kg) & 0.64 & Absorbed water (FA) (Kg) & 0.64 & Absorbed water (FA) (Kg) & 0.64 \\
\hline Results & & Results & & Results & & Results & \\
\hline Slump (mm) & 33 & Slump (mm) & 36 & Slump (mm) & 40 & Slump (mm) & 43 \\
\hline Compaction Factor & 0.9 & Compaction Factor & 0.9 & Compaction Factor & 0.9 & Compaction Factor & 0.91 \\
\hline Cement $\left(\mathrm{kg} / \mathrm{m}^{3}\right)$ & $270 \mathrm{~kg} / \mathrm{m}^{3}$ & Cement $\left(\mathrm{kg} / \mathrm{m}^{3}\right)$ & $270 \mathrm{~kg} / \mathrm{m}^{3}$ & Cement $\left(\mathrm{kg} / \mathrm{m}^{3}\right)$ & $270 \mathrm{~kg} / \mathrm{m}^{3}$ & Cement $\left(\mathrm{kg} / \mathrm{m}^{3}\right)$ & $270 \mathrm{~kg} / \mathrm{m}^{3}$ \\
\hline Density Compacted concrete $\left(\mathrm{kg} / \mathrm{m}^{3}\right)$ & 2313 & Density Compacted concrete $\left(\mathrm{kg} / \mathrm{m}^{3}\right.$ & 2310 & Density Compacted concrete $\left(\mathrm{kg} / \mathrm{m}^{3}\right)$ & 2300 & Density Compacted concrete $\left(\mathrm{kg} / \mathrm{m}^{3}\right)$ & 2296 \\
\hline
\end{tabular}




\section{Effect of copper tailings on concrete workability}

Figure 4 shows the gradual increase in the slump or workability of the concrete in relation to the increase in the partial replacement of sand with copper tailings. This indicates that the introduction of copper tailings from TD 25 in concrete increases the concrete workability. 30\% replacement of sand with copper tailings resulted in an increase of the slump by $5 \mathrm{~mm}(100 \%)$, from $5 \mathrm{~mm}$ to $10 \mathrm{~mm}$ for the low workability concrete based on 0.3 water-cement ratio. It must be mentioned at this stage that the 0.3 water-cement ratio concrete is so dry that it would need the introduction of super plasticiser for practical handling of large concrete production.

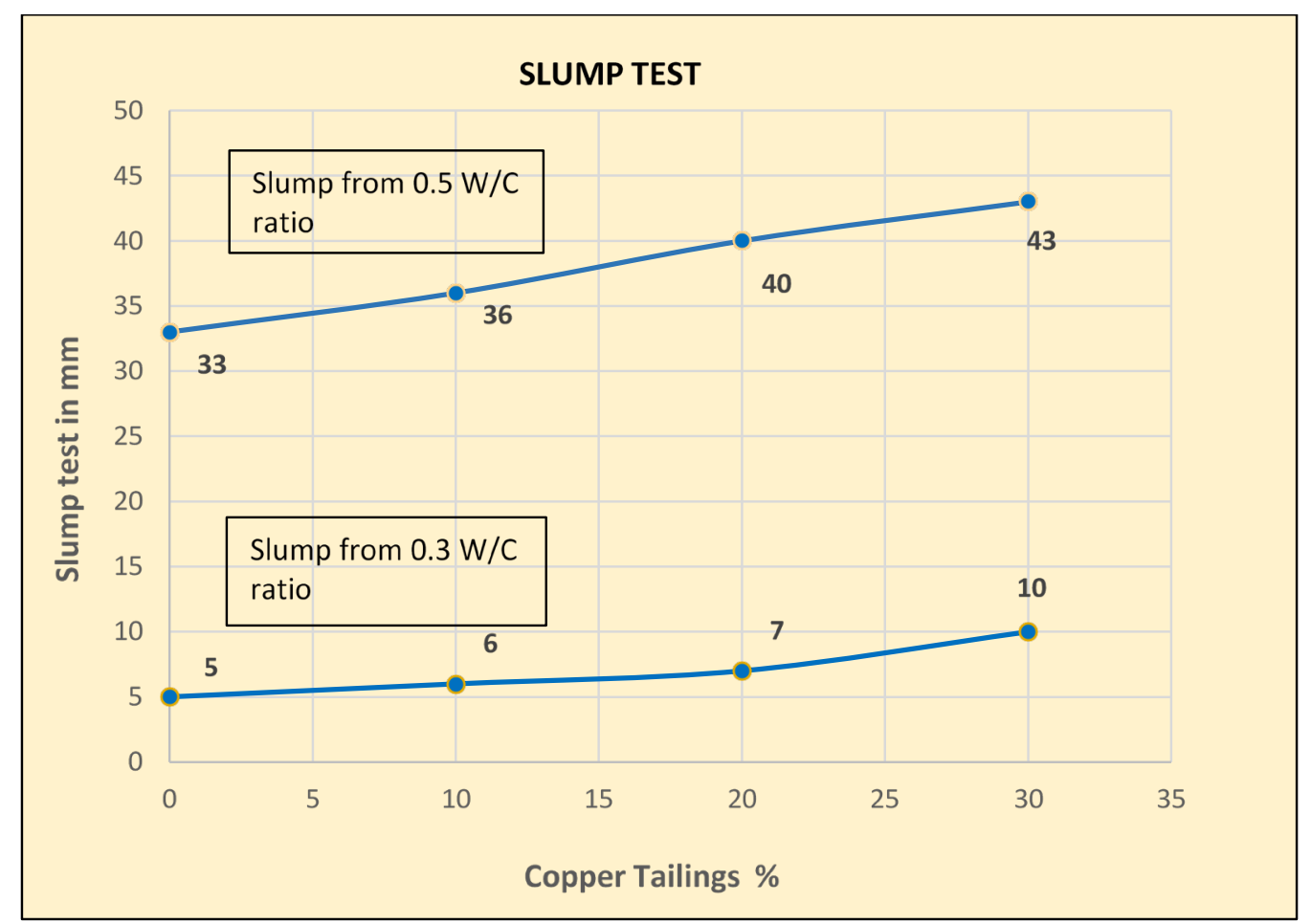

Figure 4: Graphical presentation of the slump test at 0.3 and $0.5 \mathrm{~W} / \mathrm{C}$ ratio

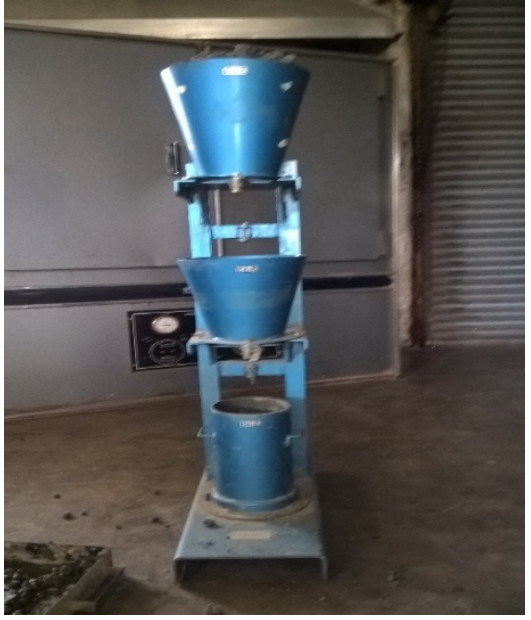

Insert Plate 5: Compaction test for concrete workability

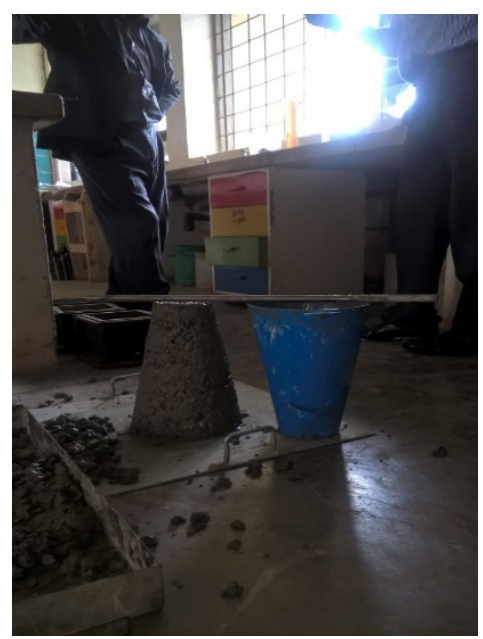

Insert Plate 6: Slump test for concrete workability

Figure 4 shows the gradual increase in the slump or workability of the 0.5 water-cement ratio concrete in relation to the increase in the partial replacement of sand with copper tailings. $30 \%$ replacement of sand with copper tailings resulted in an increase of the slump by $10 \mathrm{~mm}(30.3 \%)$ 
from $33 \mathrm{~mm}$ to $43 \mathrm{~mm}$. These results confirm the consistent workability effect of the copper tailings on concrete regardless of the water-cement ratio. The increase in workability shown by both the slump and compaction factor tests on fresh concrete for the two different water-cement $\mathrm{w} / \mathrm{c}$ ratios was because of the silt nature of the copper tailings. This result confirms the statement by Mulenga (2017) that in its saturated state; copper tailings absorb a higher percentage of moisture content as compared to saturated concrete sand and therefore, a direct proportion relationship can be established between copper tailings partial replacement of sand and workability of the fresh concrete.

\section{Effect of copper tailings on concrete compressive strength}

Figure 5 shows the effect of copper tailings from TD 25 on the compressive strength of concrete concerning a gradual increase in copper tailings partially replacing sand by up to $30 \% .10 \%$ replacement of sand with copper tailings reduced the compressive strength of the $0.3 \mathrm{~W} / \mathrm{C}$ ratio high strength concrete from $35.5 \mathrm{MPa}$ to $25 \mathrm{MPa}$ representing a reduction of $10.5 \mathrm{MPa}$. As for the $0.5, \mathrm{~W} / \mathrm{C}$ ratio concrete $10 \%$ replacement reduced the concrete strength by $2 \mathrm{MPa}$ only from $25 \mathrm{MPa}$ to $23 \mathrm{MPa}$. The study's ironic outcome was the $30 \%$ sand replacement result with was identified as the optimum partial replacement sand replacement mark. The $0.3 \mathrm{~W} / \mathrm{C}$ ratio and $0.5 \mathrm{~W} / \mathrm{C}$ ratio produced $23 \mathrm{MPa}$ and $20 \mathrm{MPa}$ respectively. Both grades of concrete can be used in foundation footings, driveways, walkways, simple retaining wall, floor slabs and in mass concrete. Both mixes at 30\% replacement still show acceptable functional properties needed for light to medium duty concrete with the drier mix manifesting higher superiority in terms of compressive strength. This is similar to the findings of Esmaeili et al (2020).

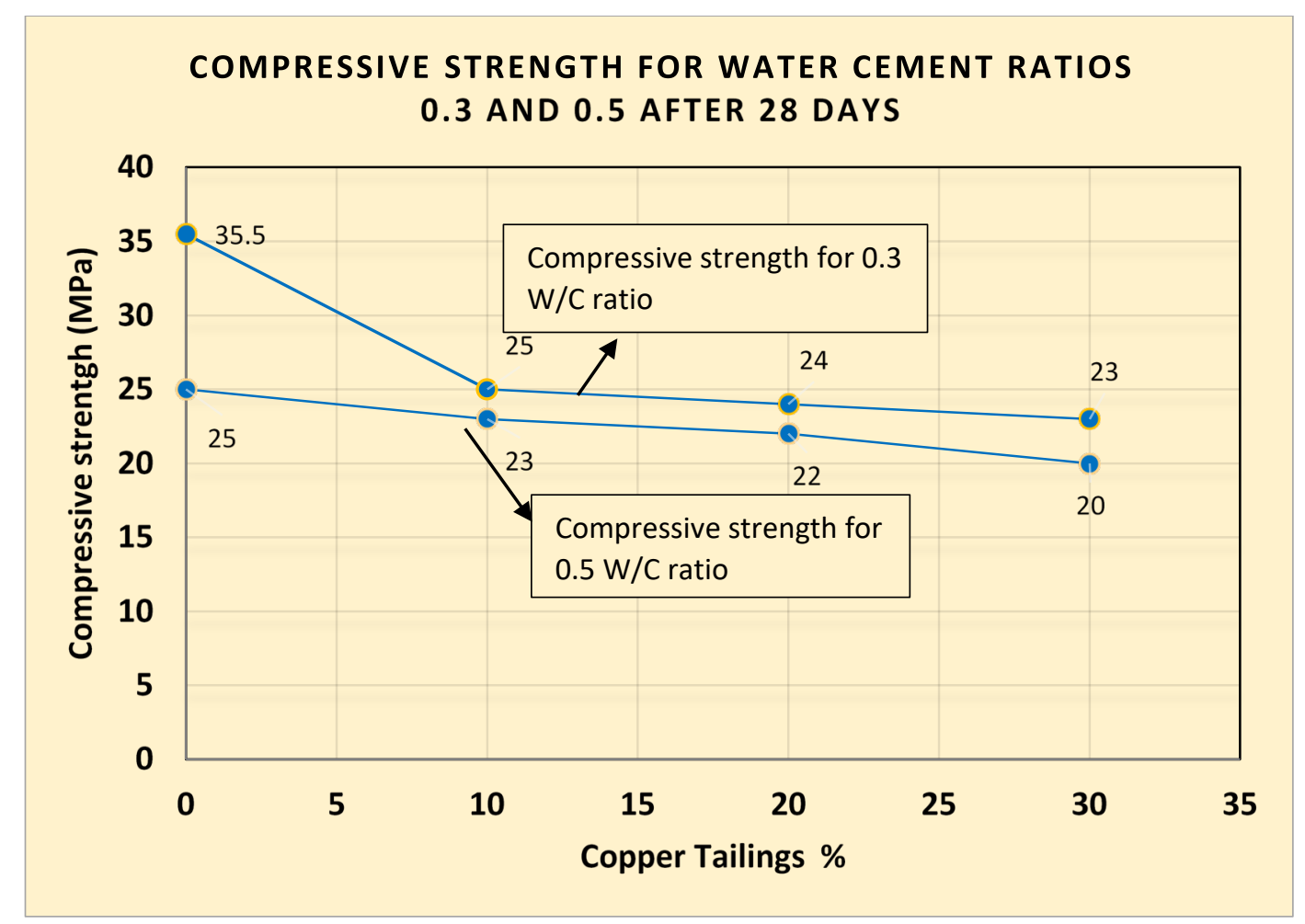

Figure 5: Graphical presentation of compressive strength for 0.3 and $0.5 \mathrm{~W} / \mathrm{C}$ ratio 
The $0.3 \mathrm{~W} / \mathrm{C}$ mix is stronger by $3 \mathrm{MPa}$ after 28 days. The cost-benefit analysis of the sand replacement with copper tailings is presented in figures 7,8 and 9 followed by a discussion of the same results. The cost-benefit of this project was one of the major driving factors in this research in addition to the absorption of copper tailing from the environment for waste recycling and creation of land for development.

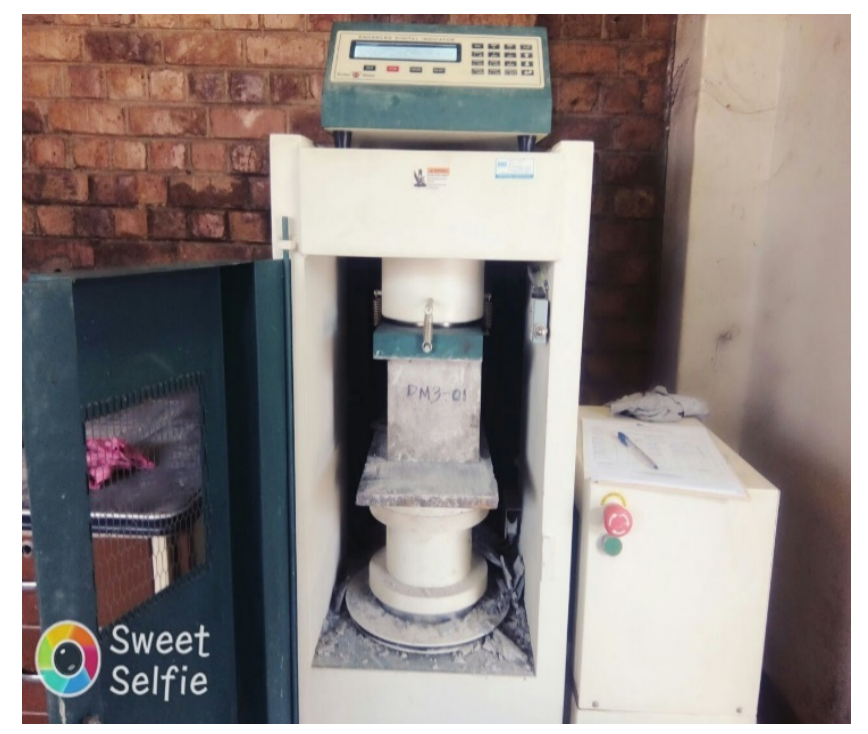

Plate 7: Compressive testing machine crushing the cube for compressive strength

\section{Effect of copper tailings on concrete density}

Figure 6 shows the concrete density changes between 0.3 and 0.5 water-cement ratios when increasing partial replacement quantities of sand with copper tailings. The 0.3 water-cement ratio mix had higher densities compared to the 0.5 water-cement ratio mix. It must be however noted that the density was reducing with an increase in the copper tailing percentage but staying the acceptable ranges of the density of above $2,100 \mathrm{~kg} / \mathrm{m}^{3}$. The 0.5 water-cement ratio also showed decreasing density when increasing replacement quantities with copper tailings. The ironic result was that both the 0.3 and 0.5 water-cement ratio had the same density of $2,296 \mathrm{~kg} \cdot \mathrm{m}^{3}$ at $30 \%$ sand replacement with copper tailings. The reduction in density is expected because of the silt and fine nature of the tailings. The 30\% sand replacement with copper tailings still provided acceptable concrete density at the optimal sand replacement of $30 \%$ by copper tailings. The concrete society of Southern Africa states that while the theoretical density of concrete is $2400 \mathrm{~kg} / \mathrm{m}^{3}$, lower density concrete gives the advantage of reduced weight except in circumstances where there is a requirement for radiation shielding or as a counterweight. 


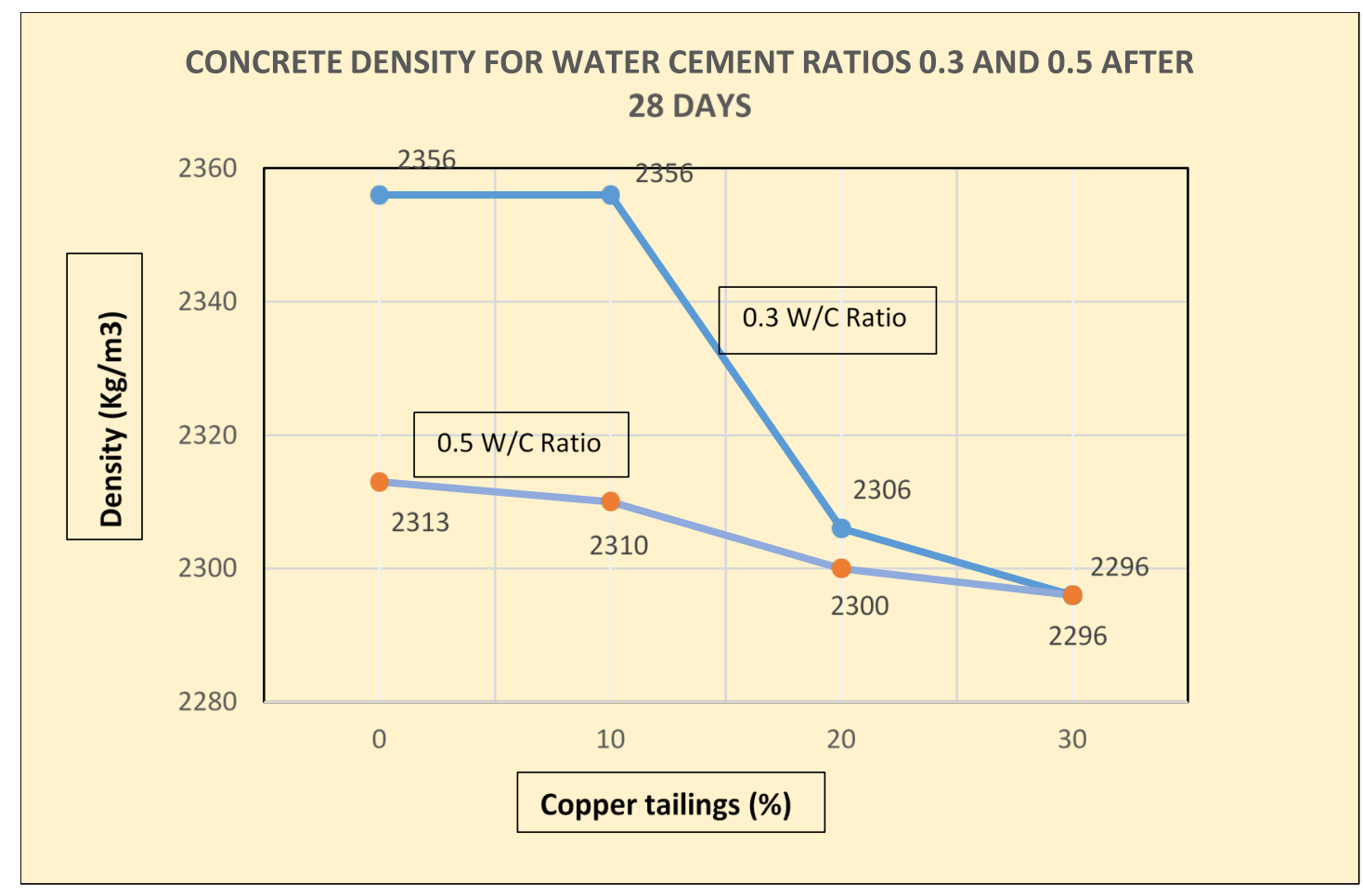

Figure 6: Graphical presentation of density for 0.3 and $0.5 \mathrm{~W} / \mathrm{C}$ ratio

\section{Cost-benefit analysis of copper tailings-based concrete}

Figure 7 and figure 8 shows the cost savings per cubic metre of concrete based on the partial replacement of sand by copper tailings form TD25. Results show that the $30 \%$ sand replacement provides maximum cost savings of K32 per cubic metre for both water-cement ratios. The saving is insignificant for low volumes of concrete however, the benefits are much higher for higher volumes of concrete as demonstrated in figure 9. This shows that for $30 \%$ partial sand replacement, the saving from $1000 \mathrm{~m}^{3}$ of concrete is $\mathrm{K} 32,000$ equivalent to the US $\$ 2,133$ at the exchange rate of $1: 15.10 \%$ replacement of sand on the other hand results in a saving of $\mathrm{K} 10,000$ for every $1,000 \mathrm{~m}^{3}$. The entire TD 25 is estimated to contribute to the production of 45 million cubic metres of low-cost concrete based on the copper tailings. Results clearly show that the optimum replacement of sand with copper tailings at $30 \%$ both in terms of cost-saving and compressive strength of the concrete are attainable. There is no difference in savings between 0.3 and 0.5 water-cement ratios except that the 0.5 water-cement ratiobased concrete is cheaper by $\mathrm{K} 190 / \mathrm{m}^{3}$ because of the less cement content which is very significant. 


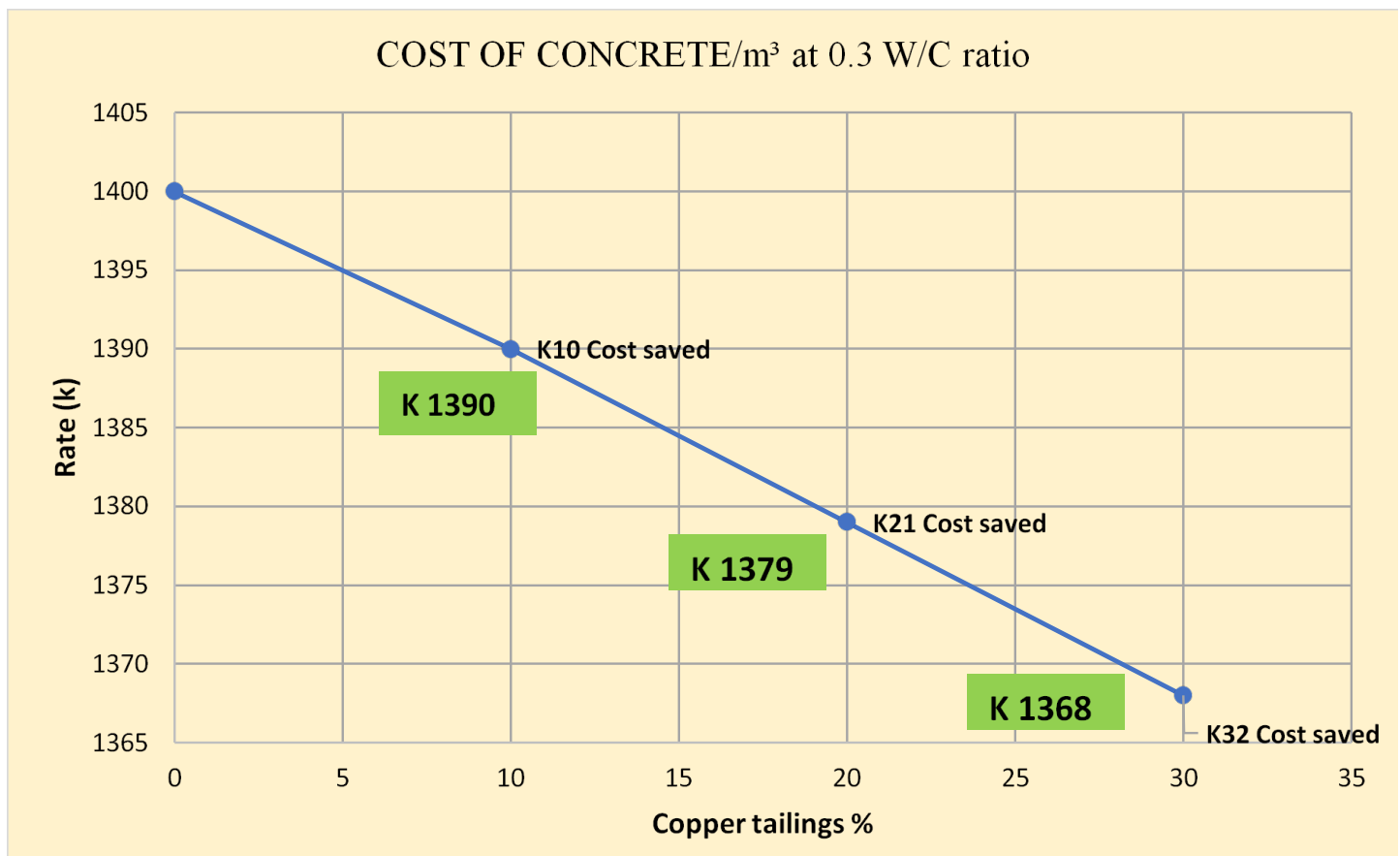

Figure 7: Graphical presentation of concrete cost per $\mathrm{m}^{3}$ for the $30 \%$ partial sand replacement with copper tailings based on the 0.3 water-cement ratio.

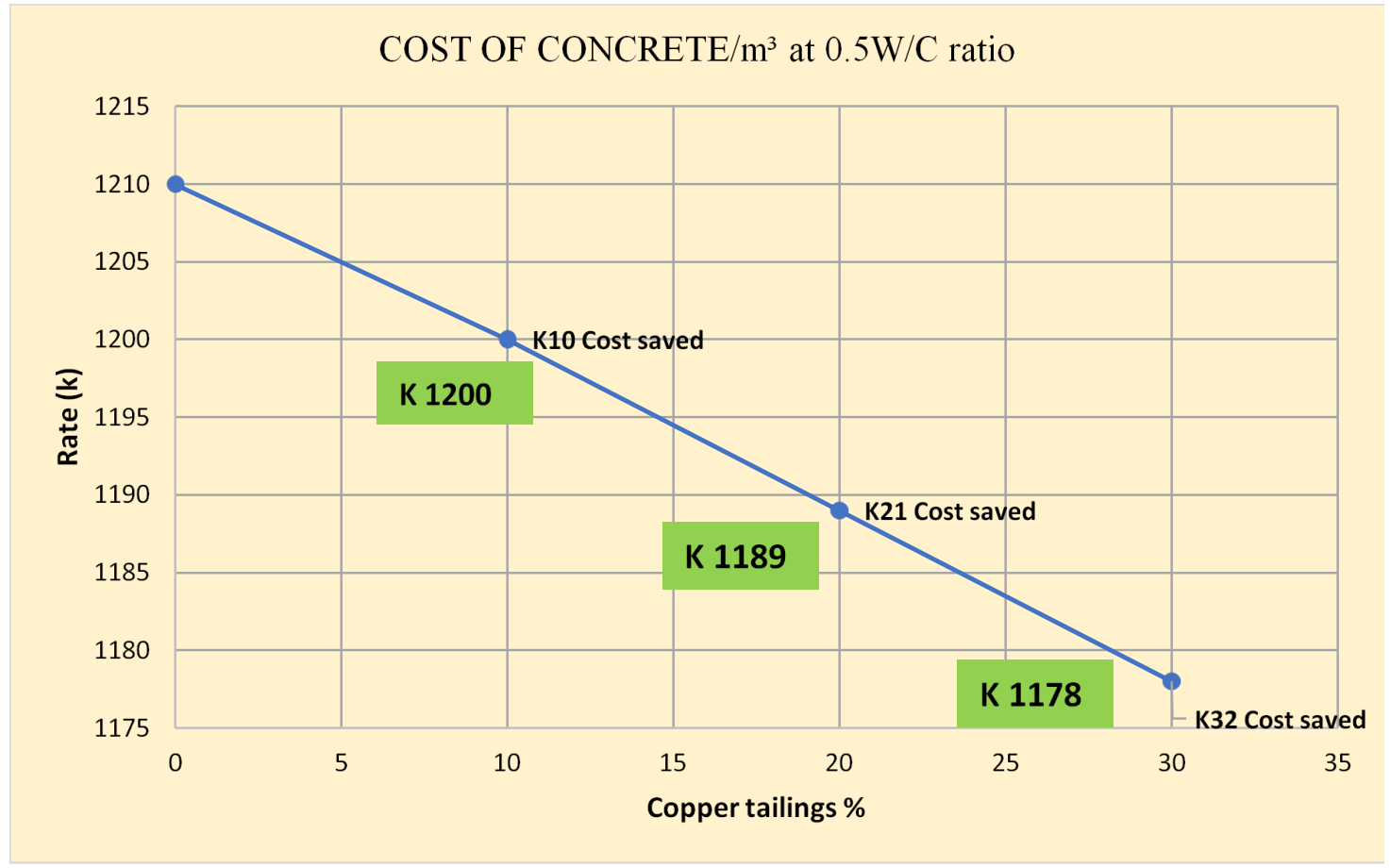

Figure 8: Graphical presentation of concrete cost per $\mathrm{m}^{3}$ for the $30 \%$ partial sand replacement with copper tailings based on the 0.5 water-cement ratio. 


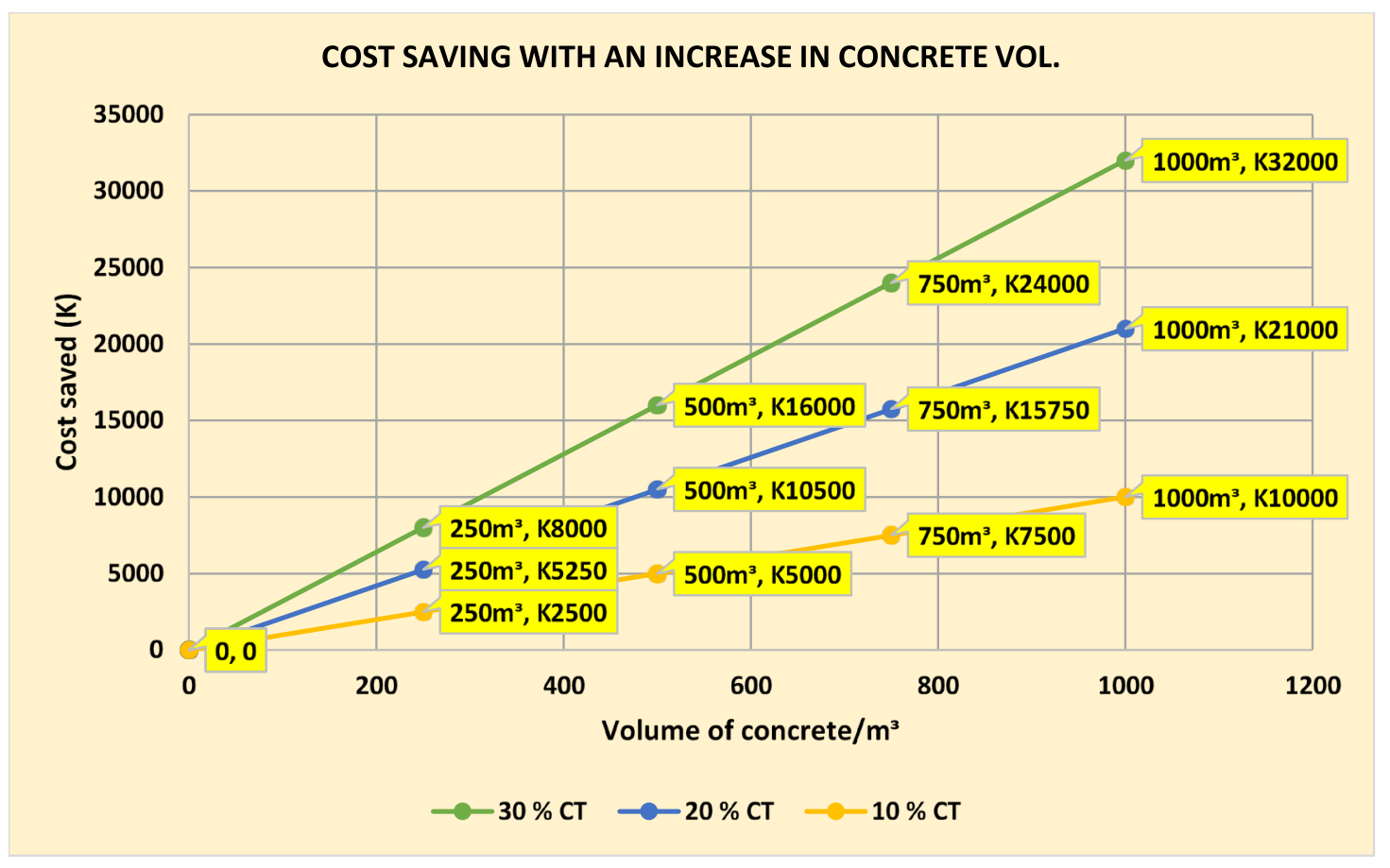

Figure 9: Graphical presentation of concrete cost per $\mathrm{m}^{3}$ for all partial replacement percentages partial sand replacement with copper tailings based on the 0.3 water-cement ratio.

\section{Value and benefits of the research to the industry}

The research results revealed that the coper tailings-based concrete can be used in Zambian construction industry for all concrete needs ranging from 20 to $25 \mathrm{Mpa}$ at minimum acceptable concrete maturity period of 28 days. According to literature and industry practice, this range of concrete grade is widely used in structural and non-structural concrete members. Industry practice can benefit from the use of this concrete based on these experimental results. Further, the cost-saving attained from this 30\% copper tailing content-based concrete was worked out the demonstrate the significance of the cost reduction and eco-friendly concrete as an evidencebased guide to users of this sustainable concrete which met all the engineering and performance requirement. A study by Gupta et al., (2017) shows that increasing copper tailings to replace fine aggregate only increased the compressive strength by $1 \mathrm{MPa}$ after at $20 \%$ copper tailing content. Further increase of copper tailings resulted in the reduction of concrete compressive strength. Higher maturity concrete at 90days resulted in concrete compressive strength increasing by a maximum of 5Mpa. Another study by Sunil et al., (2015) shows that the introduction of tailings gradually reduced the compressive strength of concrete with an increase in copper tailings. The curing days for this study were 7,28, 56 and 90 days and yet the gain in strength after 28 days was not significant with just over $5 \mathrm{MPa}$ increase after 90 days at $20 \%$ tailings introduction. Results clearly show that additional replacement of fine aggregate or cement in concrete with tailings ca gradually reduce the concrete strength. Results from a study by Jankovic et al., (2015) shows that the optimum replacement of fine aggregate with copper tailings in concrete was $10 \%$ after which the strength began to drop with a maximum concrete cube maturity period of 28 days. It can, therefore, be concluded based on other studies that longer curing periods of optimum tailings can increase compressive strength by a small margin and not necessarily increasing copper tailing percentage content to replace traditional concrete materials The current result from this paper indicate the functional and cost-effective nature of the $30 \%$ fine aggregate replacement by copper tailings which industry can adopt for implementation. However additional experiments will increase the understanding of other 
parameters of this concrete as explained in the limitations of the study in the next subheading. It also clear that the source and properties of copper tailings are unique and must, therefore, be investigated for performance despite the results and literature review showing 30\% as optimum replacement of traditional materials which include cement and fine aggregate. Of the many studies done, this is the first known paper to have done a detailed cost-benefit analysis for the benefit of the industry.

\section{Limitations of the research}

The research focussed on the concrete properties acceptable for application in industry as explained in the value and benefits part of this part of the research. Being an exploratory study focussing on the 28-day copper tailing-based concrete cured between 20 and 25Mpa, other experiments such as concrete cumulative strength from 7 to 21 days, concrete properties beyond 28 days for normal concrete and copper tailing-based concrete were not done because the primary requirements of concrete performance needed to be established in this exploratory research. The results from this study have since attracted funding from the World Bank centre of excellency for sustainability to carry out detailed experiments as described above. This will include more concrete experiments for curing periods ranging from 7 days to 90 days. Other tests to be considered under the next funded research will include water permeability, abrasion resistance, compressive strength developing monitoring, flexural tensile strength and increased copper tailing content analysis. Additional tests of concrete by increasing concrete cubes will not add value to the concrete but simple increase understanding of the copper tailing based concrete behaviour from low maturity to high maturity. Copper tailing content beyond $30 \%$ of sand replacement will not significantly increase the strength of the concrete but instead, facilitate the understanding of its behaviour. The proposed study will also include the introduction of fly ash into the experimental equation and the construction of a demonstration building constructed by using partially replaced traditional concrete materials

\section{Conclusion}

This research reveals that many studies have been undertaken on partial replacement of sand and cement in concrete production mainly up to $30 \%$ partial replacement to produce good and functional concrete. Further, the research established that it was feasible to utilise copper tailings as a way of freeing upland covered by tailings for development on the prime land. Results from this study indicate that the optimal sand replacement by copper tailings from TD 25 was $30 \%$ which resulted in concrete compressive strength of $23 \mathrm{Mpa}$ and $20 \mathrm{MPa} 0.3$ and 0.5 $\mathrm{W} / \mathrm{C}$ ratio respectively. This concrete grade can be used in foundation footings, driveways and other medium-duty concrete requirements. Unlike many other papers on the same subject, this paper presents cost and land use benefit analysis. Results further indicated that cost benefits were applicable to bulk volumes of cheaper concrete production with savings of K32,000 or US $\$ 2,133$ for every $1,000 \mathrm{~m}^{3}$ of concrete produced. In addition to these established benefits of the tailings from TD 25, approximately 111 hectares of prime land would be created for infrastructure development such as housing units, schools, health centres and other key city installations. The study recommends that the handling of these copper tailings-based concrete be given to specific and certified competent institutions for quality control and monitoring process. The study further provides a road map for analysing other copper tailing dam currently existing in Zambia and other copper producing countries for potential production of concrete and creation of land for development. This research has provided useful data that can be used to make informed decisions by local authorities in the utilisation of copper tailings as concrete resource material. One limitation of the study is that the strength tests at 60 and 90 days were 
not carried out, therefore, future studies could consider carrying out strength tests beyond 28 days in addition to replicating this study to other copper tailing dams within the country.

\section{References}

Banda, M.P. (1993), Waste management for mine solid waste, [online]. Available at: http://www.imwa.info [Accessed: 22nd November, 2006

Bandhopadhyay, A.K., Labarbe, P. and Zarzycki, (1993), Nucleation and crystallization studies of a basalt glass ceramic by small angle neutron scattering. J. Mater. Sci., 18, pp. 709.

Beniwal, P., Kumar, R., Usman, M. and Sangwan, S. (2015), Use of copper tailings as the partial replacement of sand in concrete. Int. J. Res. in Appl. Sci. \& Eng. Technology (IJRASET), 3, pp.1-6.

Bridge, B. (2000), The social regulation of resource access and environmental impact: production, nature and contradiction in the US copper industry. Geoforum, 31(1), pp 237-256.

Chen, Y., Zhang, Y., Chen, T., Zhao, Y. and Bao, S. (2011), Preparation of eco-friendly construction bricks from hematite tailings. Construction and Building Materials, 25(4), pp.2107-2111.

Çoruh, S., Ergun, O.N. and Cheng, T.W. (2002), Treatment of copper industry waste and production of sintered glass-ceramic. Waste management \& research, 24(3), pp.234241.

Creswell, J. W., (2009), Research Design Qualitative, Quantitative and Mixed Methods Approaches. $3^{\text {rd }}$ edition. Los Angeles: SAGE Publications Inc.

Edraki, M., Baumgartl, T., Manlapig, E., Bradshaw, D., Franks, D.M. and Moran, C.J. (2014), Designing mine tailings for better environmental, social and economic outcomes: a review of alternative approaches. Journal of Cleaner Production, 84, pp.411-420.

Emmitt, S. and Gorse, C.A. (2014), Advanced construction of buildings. 3rd edition. UK: John Wiley \& Sons, Ltd.

Esmaeili, J. and Aslani, H. (2019), Use of copper mine tailing in concrete: strength characteristics and durability performance. Journal of Material Cycles and Waste Management, 21(3), pp.729-741.

Esmaeili, J., Aslani, H. and Onuaguluchi, O. (2020), Reuse Potentials of Copper Mine Tailings in Mortar and Concrete Composites. Journal of Materials in Civil Engineering, 32(5), p.04020084.

Feng-qing, Z., Jing, Z. and Hong-jie, L. (2009), Autoclaved brick from low-silicon tailings. Constr. Build Mater, 23, pp. 538-41.

Gou, M., Zhou, L. and Then, N. (2019), Utilization of tailings in cement and concrete: A review, Science and Engineering of Composite Materials, 26(1), 449-464. doi: https://doi.org/10.1515/secm-2019-0029.

Gupta, R.C., Mehra, P. and Thomas, B.S. (2017), Utilization of copper tailing in developing sustainable and durable concrete. Journal of Materials in Civil Engineering, 29(5), p.04016274.

Hallingberg, B., Turley, R., Segrott, J., Wight, D., Craig, P., Moore, L., Murphy, S., Robling, M., Simpson, S.A. and Moore, G, (2018), Exploratory studies to decide whether and how to proceed with full-scale evaluations of public health interventions: a systematic review of guidance. Pilot and feasibility studies, 4(1), p.104. 
Huang, X.Y., Ni, W., Cui, W.H., Wang, Z.J. and Zhu, L.P. (2012), Preparation of autoclaved aerated concrete using copper tailings and blast furnace slag. Construction and Building Materials, 27(1), pp.1-5.

Janković, K., Bojović, D., Stojanović, M. and Lončar, L., (2015), The use of mine tailings as a partial aggregate replacement in SCC concrete, International Conference. Contemporary achievements in civil engineering, Serbia..

Kitwe map showing tailing dams TD25 and TD 26, https://www.xenocanto.org/location/map?lat=-

$12.8158 \&$ long $=28.2237 \&$ loc $=$ Kitwe + Tailings + Dam $\% 2 \mathrm{C}+$ Kitwe $\% 2 \mathrm{C}+$ Copperbelt., accessded 25/04/2020

Kumar, R. (1996). Research Methodology. London: SAGE Publication Ltd.

Kumar, V. S. and Skariah, T. B. (2012), Utilisation of solid waste particles as aggregates in concrete. Procedia Engineering, 38, pp3789-96.

Liapis, I and Likoydis S. (2012), Use of electric arc furnace slag in thin skid-resistant surfacing. Procedia - Soc Behav Sci., 48, pp. 907-18.

Lindahl Joanna .(2014). Environmental impacts of mining in Zambia Towards better environmental management and sustainable exploitation of mineral resources, Geological survey of Sweden, http://resource.sgu.se/produkter/sgurapp/s1422rapport.pdf, accessed 15/04/2020.

Maza, M., Naceri, A. and Zitouni,S. (2015), Physico-mechanical properties of mortar made with binary natural fine aggregates (dune sand and crushed sand) with and without chemical admixture, Asian journal of civil engineering (bhrc) vol. 17, no. 5(2016) pages 663-682.

Marghussian, V.K. and Maghsoodipoor, A. (1999), Fabrication of unglazed floor tiles containing Iranian copper slag. Ceram Int., 25, pp. 617-22.

Motz, H. and Geiseler, J. (2001), Products of copper tailings an opportunity to save natural resources. Waste Management, 21, pp. 285-93.

Mulenga, B. (2017), Investigating the use of copper tailings as a partial replacement of sand in concrete in Zambia, Copperbelt University, Zambia, unpublished thesis.

Muleya, F. (2015), Modelling of wheeled construction performance in clay and sandy terrain: A terramechanics perspective. Unpublished PhD Thesis, Anglia Ruskin University, England.

Onuaguluchi, O. and Eren, O. (2012), Recycling of copper tailings as an additive in cement mortars. Construction and Building Materials, 37(1), pp 723-727.

Parthasarathi, N., Reddy, B.R. and Satyanarayanan, K.S., (2016). Effect on workability of concrete due to partial replacement of natural sand with gold mine tailings. Indian J. Sci. \& Technology, 9, pp.1-4.

Pasetto, M. and Baldo, N. (2011), Experimental evaluation of high-performance base course and road base asphalt concrete with electric arc furnace steel slags. Hazard Mater, 181, pp. 938-48.

Possan, E., Felix, E.F. and Thomaz, W.A. (2016), $\mathrm{CO}_{2}$ uptake by carbonation of concrete during life cycle of building structures. Journal of Building Rehabilitation 1, 7 (2016). https://doi.org/10.1007/s41024-016-0010-9.

Preethi, A.V., Rajendra, S. and Navneeth, P.K.L., (2017), Studies on Gold Ore Tailings as Partial Replacement of Fine Aggregates in Concrete. Int. J. Latest. Technol. Eng. Manag. Appl. Sci., 6(IV), pp.30-33.

Saxena, M and Dhimole, L. K. (2006), Utilization and value addition of copper tailing as an extender for development of paints. Journal of Hazardous Materials, B129, pp. 5057. 
Saxena, M. and Gowri, V.S. (2002), Innovative building materials. Civil Engineering Construction. Rev, 15, pp. 46-50.

Saxena, M., Asokan, P. and Morchhale, R.K. (2004), Durability characteristics of fired clay and clay fly ash bricks, in: Proceeding of the National Seminar on Recent Trends in Building Materials, RRL, Bhopal, pp. 328-333.

Senthamarai, R. M. and Devadas, M. P. (2005, Concrete with ceramic waste aggregate, Cement Concrete Composition, 27 (9-10), Pp 910-913.

Shamsai, A., Pak, A., Bateni, S.M. and Ayatollahi, S.A.H. (2007). Geotechnical characteristics of copper mine tailings: a case study. Geotechnical and geological engineering, 25(5), pp.591-602.

Shettima, A.U., Hussin, M.W., Ahmad, Y. and Mirza, J. (2016), Evaluation of iron ore tailings as replacement for fine aggregate in concrete. Construction and Building Materials, 120, pp.72-79.

Sikaundi, G. (2008), Copper Mining Industry in Zambia Environmental Challenges, Environmental council of Zambia, https://unstats.un.org/unsd/environment/envpdf/UNSD_UNEP_ECA\%20Workshop/ Session $\% 2008-5 \% 20$ Mining\%20in\%20Zambia\%20(Zambia).pdf, $\quad$ accessed $15 / 04 / 2020$.

Siluonde, H. (2016), Developing alternative roof tiles from plastic waste and copper tailings, Copperbelt University, Zambia, unpublished thesis.

Sorlini, S., Sanzeni A. and Rondi L., 2012. Reuse of steel slag in bituminous paving mixtures. J Hazard Mater, 209, pp. 84-91.

Sultan, H. A. (1979), Stabilized copper mill tailings for highway construction. Transp Res Rec (734).

Sunil, B.M., Manjunatha, L.S., Ravi, L. and Yaragal, S.C. (2015), Potential use of mine tailings and fly ash in concrete. Advances in concrete construction, 3(1), p.055.

Thomas, B.S., Damare, A. and Gupta, R.C. (2013), Strength and durability characteristics of copper tailing concrete. Construction and Building Materials, 48, pp.894-900.

World Bank, (2011), What would it take for Zambia's copper mining industry to achieve its potential? [online].

Yamba, F.D. (2004), National Solid Waste Management Strategy for Zambia, Lusaka: Environmental Council of Zambia.

Zambia Mining Environment Remediation and Improvement Project (2016), environmental and social management framework, Ministry of Mines and mineral development. http://documents.shihang.org/curated/zh/813951469077929423/pdf/SFG2338-EAP154683-Box396279B-PUBLIC-disclosed-7-20-16.pdf, accessed 15/04/2020. 